\title{
Analisis Penataan Sel Untuk Layanan Sistem WCDMA di Area Jalan Tengah I Kerobokan
}

\author{
Ketut Alit Sukertha Winaya ${ }^{1}$, Gede Sukadarmika ${ }^{2}$ Linawati $^{3}$
}

\begin{abstract}
In WCDMA celuller system, coverage area is a determinant of the quality network services. To provide maximum network services at Jl. Tengah I Kerobokan, calculated by Propagation model the most appropriate to the conditions of BTS Protpeliatan sector $\gamma$ and BTS AnyarKaja sector $\beta$, then determine the azimuth direction and tilting the right antenna. The most appropriate Propagation models has found to BTS Protpeliatan sector $\gamma$ called Okumurra Hatta model and for BTS AnyarKaja Sector $\beta$ is Cost 231 Hatta model, the distance of maximum service coverage BTS Protpeliatan sector $\gamma$ is the extent of $1.17 \mathrm{~km}$ and a distance of $1,11 \mathrm{~km}$ to the BTS AnyarKaja sector $\beta$. The antenna tilt of BTS Protpeliatan Sector $\gamma$ need to change from $0^{\circ}$ to $0^{\circ} 5^{\circ}$, BTS AnyarKaja sector $\beta$ need to change in antenna tilt of $0^{\circ}$ to $1^{\circ}$ and change directions of antenna sectorization of $20^{\circ}$ from $180^{\circ}$ to $200^{\circ}$. From the simulation results prediction coverage signal area is performed using software Atoll with these parameters, it is known that the area of Jl. Tengah I Kerobokan has gained maximum service with signal reception level that meets the Key Performance Indictator's standard.
\end{abstract}

Intisari - Dalam sistem WCDMA, Cakupan layanan sinyal merupakan penentu kualitas layanan jaringan. Untuk memberikan layanan jaringan yang maksimal di area Jl. Tengah I Kerobokan maka dilakukan perhitungan model propagasi yang paling sesuai dengan kondisi BTS Protpeliatan Sektor $\gamma$ dan BTS AnyarKaja Sektor $\beta$, kemudian melakukan penentuan arah azimuth dan tilting antena yang tepat. Didapatkan bahwa model propagasi yang paling sesuai dengan BTS Protpeliatan Sektor $\gamma$ adalah model Okumurra Hatta dan BTS AnyarKaja Sektor $\beta$ adalah model Cost 231 Hatta, jarak cakupan layanan maksimum BTS Protpeliatan Sektor $\gamma$ adalah sejauh 1,17 km dan sejauh 1, $11 \mathrm{~km}$ pada BTS AnyarKaja Sektor ß. Diperlukan perubahan tilt antena dari $0^{\circ}$ menjadi $0,95^{\circ}$ pada BTS Protpeliatan Sektor $\gamma$ dan perubahan sudut tilt dari $0^{\circ}$ menjadi $1^{\circ}$ serta perubahan arah sekorisasi antena sebesar $20^{\circ}$ dari $180^{\circ}$ menjadi $200^{\circ}$ pada BTS AnyarKaja Sektor $\beta$. Dari hasil simulasi prediksi cakupan layanan sinyal yang dilakukan menggunakan software Atoll dengan parameter tersebut diketahui bahwa area Jl. Tengah I Kerobokan telah mendapatkan layanan yang maksimal dengan level penerimaan sinyal yang telah memenuhi standar KPI (Key Performance Indictator).

${ }^{1}$ Mahasiswa, Jurusan Teknik Elektro dan Komputer Fakultas Teknik Universitas Udayana, Jln. Kampus Bukit Jimbaran 80361 INDONESIA (telp: 0361-703315; fax: 0361-4321; e-mail: alitswinaya@gmail.com

2,3 Dosen, Jurusan Teknik Elektro dan Komputer Fakultas Teknik Universitas Udayana, Jln. Kampus Bukit Jimbaran 80361 INDONESIA (telp: 0361-703315; fax: 0361-4321; e-mail:

${ }_{1}^{1}$ sukadarmika@unud.ac.id, ${ }^{2}$ linawati@unud.ac.id

Ketut Alit Sukertha Winaya: Analisis Penataan Sel Untuk ...
Kata kunci : Cakupan layanan, BTS, model propagasi, tilt, sektorisasi, antena, Atoll, WCDMA.

\section{Pendahuluan}

Perkembangan bidang telekomunikasi berlangsung begitu pesat seiring dengan kemajuan ilmu pengetahuan dan teknologi sehingga masyarakat akan selalu menghendaki ketersediaan layanan jaringan komunikasi yang baik untuk mendukung aktivitas sehari-hari. Terkait hal tersebut, para penyedia layanan jaringan seluler berusaha untuk memberikan kualitas layanan yang baik untuk pelanggannya. Dalam sistem komunikasi seluler, hal yang menentukan kualitas sebuah jaringan komunikasi yaitu cakupan layanan (coverage area) dari BTS (Base Tranceiver Station). Diketahui bahwa area Jl. Tengah I di Kerobokan Kuta Utara tidak mendapatkan layanan jaringan WCDMA yang maksimal dari BTS ProtPeliatan sektor $\gamma$ dan BTS AnyarKaja sektor $\beta$.

Berdasarkan data hasil drive test yang dilakukan di Jl. Tengah I Kerobokan diketahui bahwa level penerimaan sinyal di area tersebut sangat buruk dimana nilai level penerimaan sinyal (RSCP) minimum berada pada level $-85 \mathrm{dBm}<\mathrm{x} \leq-120$ $\mathrm{dBm}$. Standard KPI (Key Performance Indicator) yang dikeluarkan oleh provider Tri untuk nilai RSCP minimum adalah sebesar $-85 \mathrm{dBm}$ sehingga dari data hasil drive test tersebut diketahui bahwa level penerimaan sinyal di area $\mathrm{Jl}$. Tengah I belum memenuh standard KPI.

Untuk mengoptimalkan cakupan layanan dari kedua BTS maka dibutuhkan kajian penataan sel terhadap BTS_AnyarKaja dan BTS_ProtPeliatan yang melayani area Jl. Tengah I Kerobokan dengan proses tilting dan sektorisasi antena. Tilting antena dilakukan dengan cara merubah kemiringan antena sedangkan sektorisasi dilakukan dengan cara merubah arah pancar antena.

Dengan adanya penelitian ini diharapkan coverage area yang dilayani oleh kedua BTS akan mengalami perubahan dan akan berpengaruh terhadap kualitas sinyal pada jaringan WCDMA area J1. Tengah I Kerobokan. Selain itu, untuk memvisualisasikan hasil kajian yang dilakukan maka akan dilakukan proses simulasi dengan software radio planning Atoll untuk melihat prediksi cakupan layanan sinyal yang dihasilkan.

\section{TINJAUAN PUSTAKA}

A. WCDMA (Wideband-Code Division Multiple Access)

WCDMA merupakan teknik multiple accses yang digunakan pada jaringan UMTS (Universal Mobile Telecommunication System) yang merupakan jaringan seluler generasi ketiga (3G). Jaringan UMTS ini dikenal juga dengan nama sistem WCDMA dimana prinsip kerjanya p-ISSN:1693 - 2951; e-ISSN: 2503-2372 
mengggunakan pita broadband dimana sinyal informasi akan disebarkan pada pita frekuensi yang lebih besar daripada frekuensi aslinya. Setiap informasi yang dikirimkan dalam pita frekuensi tersebut akan diberi kode khusus sehingga decoder mengetahui kode tersebut dan hanya mengambil sinyal yang dinginkan sedangkan sinyal lainnya akan dianggap sebagai noise.

Sistem WCDMA merupakan peningkatan dari sistem CDMA dimana secara keseluruhan memiliki bandwdith 5 $\mathrm{MHz}$ dan di desain dapat berdampingan dengan sistem GSM. WCDMA menggunakan 2 mode operasi yaitu Frequency Division Duplex (FDD) dan mode Time Division Duplex (TDD). Untuk mode FDD, frekuensi carrier arah uplink dan downlink dipisah dari $5 \mathrm{MHz}$, sedangkan dalam mode TDD dipakai secara bergantian antara uplink dan downlink [1].

Arsitektur jaringan dalam system WCDMA terdiri dari perangkat-perangkat yang saling mendukung, yaitu User Equipment (UE), UMTS Terresterial Radio Access Network (UTRAN) dan Core Network (CN). Terkait hal tersebut, arsitektur jaringan WCDMA ditunjukkan dalam Gambar 1 :

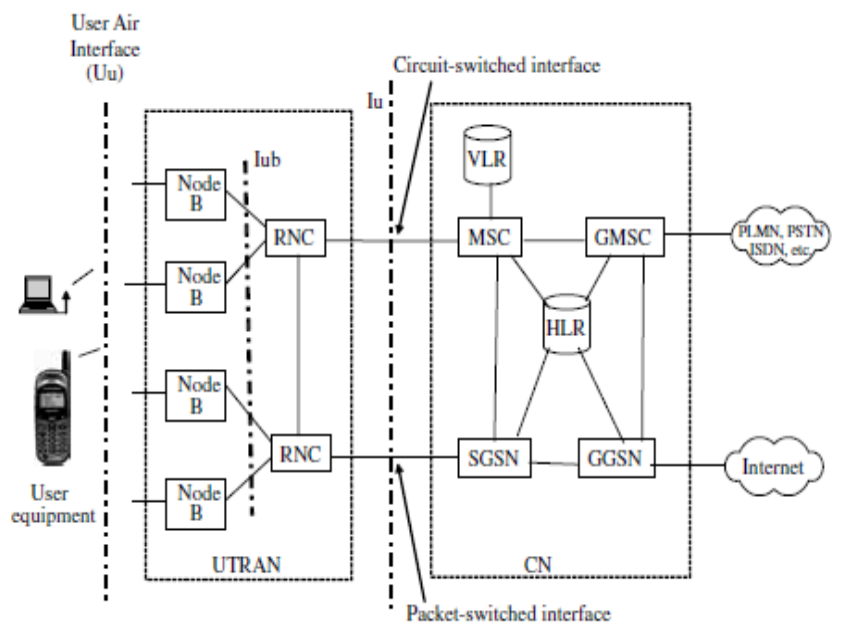

Gambar 1. Arsitektur Jaringan WCDMA [1]

Keterangan dari arsitektur jaringan WCDMA pada Gambar 1 sebagai berikut :

1) User Equipment (UE) : perangkat yang digunakan user dalam menggunakan jaringan komunikasi seluler yang dilengkapi dengan USIM yang berisi nomor identitas [1].

2) UMTS Terresterial Radio Access Network (UTRAN : jaringan akses dalam UMTS yang terdiri dari satu atau lebih jaringan sub sistem (RNS). Sebuah RNS terdiri dari Radio Network Controller (RNC) dan satu atau lebih Node-B.. Beberapa Node-B dibawahi oleh sebuah RNC yang bertugas menghubungkan Core Network $(\mathrm{CN})$ dengan user. [1]

3) Core Network (CN) : Memanajemen jaringan dan bertugas sebagai switching pada jaringan UMTS, serta berfungsi sebagai interface antara jaringan UMTS dengan jaringan lainnya. Core Network terdiri dari MSC (Mobile Switching Center), VLR (Visitor Location Register), HLR (Home Location Register), SGSN (Serving GPRS Support Node), dan GGSN (Gateway GPRS Support Node) [1].
Dalam referensi [6], alokasi frekuensi yang dipakai dalam jaringan WCDMA dapat dilihat pada Tabel 1 :

TABEL I

ALOKASI FREKUENSI SISTEM WCDMA [2]

\begin{tabular}{|c|c|}
\hline \multicolumn{2}{|c|}{ Frekuensi Sistem WCDMA } \\
\hline Mode FDD & Mode TDD \\
\hline Uplink $: 1920 \mathrm{MHz}-1980 \mathrm{MHz}$ & Uplink : $1900 \mathrm{MHz}-1920 \mathrm{MHz}$ \\
\hline Downlink : $2110 \mathrm{MHz}-2170 \mathrm{MHz}$ & Downlink: $2010 \mathrm{MHz}-2025 \mathrm{MHz}$ \\
\hline
\end{tabular}

\section{B. Link Budget Coverage Area}

Dalam perhitungan radius cakupan layanan sel, langkah pertama yang dilakukan yakni melakukan perhitungan link budget dari arah uplink (MS ke BTS) dan downlink (BTS ke MS). Link budget dapat menghitung semua gain dan loss antara pengirim dan penerima, termasuk atenuasi, penguatan/gain antena, dan loss lainnya yang dapat terjadi. Ada 2 tahap dalam menghitung link budget yaitu menghitung nilai product pathloss (Lp) dan kemudian menghitung nilai total pathloss (Lpt)

\section{Perhitungan Product Path Loss (Lp)}

Dalam menghitung nilai product pathloss (Lp) dapat mengacu pada (1) dan (2) sebagai berikut [3].

Lpuplink $=\mathrm{Pm}+\mathrm{Gm}-\mathrm{Lm}+\mathrm{Gb}+\mathrm{Gd}-\mathrm{Sb}-\mathrm{Ld}-\mathrm{Lj}$

$\mathrm{Lp}$ downlink $=\mathrm{Pb}+\mathrm{Gb}+\mathrm{Gm}-\mathrm{Sm}-\mathrm{Ld}-\mathrm{Lj}-\mathrm{Ltf}$

$$
\begin{aligned}
\text { Dimana : } & \\
\mathrm{Pm} & =\text { MS Tx Power }(\mathrm{dBm}) \\
\mathrm{Gm} & =\mathrm{MS} \text { Antena Gain }(\mathrm{dBi}) \\
\mathrm{Lm} & =\mathrm{MS} \text { Feeder Loss }(\mathrm{dB}) \\
\mathrm{Sm} & =\mathrm{MS} \text { Rx Sensitiviy }(\mathrm{dBm}) \\
\mathrm{Pb} & =\mathrm{BS} \text { Tx Power }(\mathrm{dBm}) \\
\mathrm{Gb} & =\mathrm{BS} \text { Antena Gain }(\mathrm{dBi}) \\
\mathrm{Gd} & =\mathrm{BS} \text { Diversity Gain }(\mathrm{dB}) \\
\mathrm{Sb} & =\mathrm{BS} \text { Rx Sensitivity }(\mathrm{dBm}) \\
\mathrm{Ld} & =\mathrm{BS} \text { Duplexer Loss }(\mathrm{dB}) \\
\mathrm{Lj} & =\mathrm{BS} \text { Jumper Loss }(\mathrm{dB}) \\
\mathrm{Ltf} & =\mathrm{BS} \text { Tx Filter Loss }(\mathrm{dB})
\end{aligned}
$$

2. Perhitungan Total Path Loss (Lpt)

Referensi [3] menunjukan bahwa untuk menghitung nilai total pathloss (Lpt) dapat mengacu pada (5) dan (6)

Lpt uplink = Lp uplink $-(\mathrm{Lf} / \mathrm{f})-\mathrm{Mf}-\mathrm{Ab}-\mathrm{Abd}$

$\mathrm{Lpt}$ downlink $=\mathrm{Lp}$ downlink $-(\mathrm{Lf} / \mathrm{f})-\mathrm{Mf}-\mathrm{Ab}-\mathrm{Abd}$

Keterangan :

$(\mathrm{Lf} / \mathrm{f})=$ Total Feeder Loss

$$
=(\text { feeder loss per } \mathrm{m} x \text { tinggi antena }) \mathrm{dB}
$$

Mf = Fade Margin (dB)

$\mathrm{Ab}=$ Boddy Attenuation $(\mathrm{dB})$

Abd = Building Attenuation $(\mathrm{dBi})$

C. Model Propagasi 
Nilai rugi-rugi propagasi sebuah antena akan berpengaruh terhadap cakupan layanan BTS. Pemilihan model propagasi didasarkan pada tipe daerah, ketinggian antena, dan besarnya frekuensi yang digunakan. Kedaan kontur permukaan tanah yang berbeda-beda akan berpengaruh pada cakupan layanan sebuah BTS sehingga untuk memperkirakan penentuan tilting yang sesuai dibutuhkan pemilihan model propagasi antena yang tepat. Dalam penelitian ini perhitungan propagasi antena menggunakan model propagasi Okumura Hatta dan model Cost 231 Hatta untuk kategori daerah urban.

\section{Model Propagasi Okumura Hatta}

Persamaan (8) dapat digunakan untuk menghitung rugirugi propagasi dalam propagasi Okumura Hatta di daerah urban [4].

$$
\begin{aligned}
L_{u}= & 69,55+26,16 \log -13,83 \log h_{b}+a\left(h_{m}\right)+ \\
& (44,9-6,55 \log h b) \log d
\end{aligned}
$$

dengan ,

$150 \leq f \leq 1500 \mathrm{MHz}$

$30 \leq h_{b} \leq 200 \mathrm{~m}$

$1 \leq d \leq 20 \mathrm{~km}$

$\mathrm{a}(\mathrm{hm})$ merupakan nilai aktor koreksi antena mobile yang dapat dihitung dengan mengacu pada (9)

$a\left(h_{m}\right)=3,2\left(\log 11,75 h_{m}\right)^{2}-4,97 d B$

dimana,

$L_{u}=$ Path loss rata-rata $(\mathrm{dB})$

$f \quad=$ frekuensi $(\mathrm{MHz})$

$h_{b} \quad=$ tinggi antena Base Station $(\mathrm{m})$

$h_{m}=$ tinggi antena Mobile Station (m)

$d \quad=$ jarak antara MS dan BS $(\mathrm{km})$

2. Model Propagasi Cost 231 Hatta

Referensi [4] menunjukkan bahwa perhitungan rugi-rugi propagasi antena dengan model Cost 231 Hatta dapat dihitung dengan mengacu pada (10).

$$
\begin{aligned}
L_{u}= & 46,3+33,9 \log -13,82 \log h_{b}+\quad a\left(h_{m}\right)+ \\
& (44,9-6,55 \log h b) \log d+C m
\end{aligned}
$$

dengan,

$1500 \leq f \leq 2000 \mathrm{MHz}$

$30 \leq h_{b} \leq 200 \mathrm{~m}$

$1 \mathrm{~m} \leq h_{m} \leq 10 \mathrm{~m}$

$1 \leq d \leq 20 \mathrm{~km}$

$C_{m}=0 \mathrm{~dB}$ (daerah urban)

Untuk mencari nilai a(hm) dalam propagasi Cost 231 Hatta dapat mengacu pada (9)

\section{EIRP (Effective Isotropic Radiated Power)}

EIRP merupakan besar daya yang dipancarkan oleh antena untuk menghasilkan puncak daya yang diamati pada arah radiasi maksimum dalam penguatan sebuah antenna [5].

Ketut Alit Sukertha Winaya: Analisis Penataan Sel Untuk ...
Perhitungan nilai EIRP dapat dihitung dengan mengacu pada (11)

$\mathrm{EIRP}=\mathrm{P}_{\mathrm{TX}}+\mathrm{G}_{\mathrm{TX}}-\mathrm{L}_{\mathrm{TX}}$

Dimana $\mathrm{P}_{\mathrm{TX}}$ merupakan nilai daya pancar $(\mathrm{dBm}), \mathrm{G}_{\mathrm{TX}}$ merupakan nilai penguatan antenna pemancar / gain antenna (dBi), dan $\mathrm{L}_{\mathrm{TX}}$ merupakan rugi-rugi pada antena pemacar / cable loss $(\mathrm{dBm})$.

\section{E. RSL (Received Signal Level)}

RSL merupakan nilai level kuat sinyal yang dapat diterima oleh user. Dalam jaringan WCDMA, RSL juga dikenal dengan sebutan RSCP (Received Signal Code Power). Referensi [6] menyatakan bahwa nilai RSL dapat dihitung dengan mengacu pada (12) seperti dibawah ini

$$
\begin{aligned}
\mathrm{RSL}(\mathrm{dBm})= & \text { EIRP }- \text { Wall Loss }- \text { Boddy Loss }- \text { Path Loss }- \\
& (\text { Handover }+ \text { Fading Margin })
\end{aligned}
$$

Adapun nilai KPI (Key Performance Indicator) untuk nilai RSCP yang dipakai oleh provider Tri ditunjukkan pada Tabel 2 berikut

TABEL II

\begin{tabular}{|l|l|c|}
\multicolumn{3}{|l|}{ STANDAR NILAI RSCP H3I (TRI) } \\
\hline & -120 to $-95(\mathrm{dBm})$ & Very Bad \\
\hline & -95 to $-90(\mathrm{dBm})$ & Bad \\
\hline & -90 to $-85(\mathrm{dBm})$ & Fair \\
\hline & -85 to $-83(\mathrm{dBm})$ & \multirow{2}{*}{ Good } \\
\hline & -83 to-78 $(\mathrm{dBm})$ & \multirow{2}{*}{ Very Good } \\
\hline & -78 to $-74(\mathrm{dBm})$ & \\
\hline & -74 to $0 \quad(\mathrm{dBm})$ & \\
\hline
\end{tabular}

Sedangkan untuk standar nilai RSL yang digunakan dalam simulasi menggunakan software radio planning Atoll ditunjukkan pada Gambar 2.

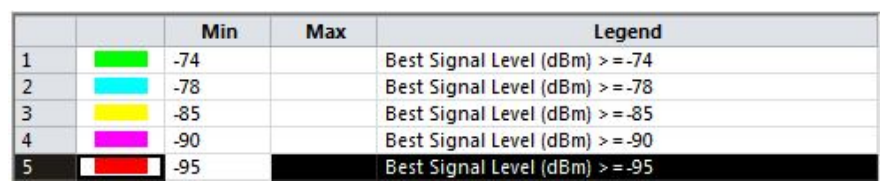

Gambar 2. Standar Nilai RSL dalam Software Atoll

\section{F. Tilting Antena.}

Tilt antena merupakan besar sudut kemiringan pada antena dengan satuan derajat, semakin besar sudutnya maka posisi antena akan semakin turun/menunduk [7]. Pada saat melakukan optimasi jaringan, pengaturan tilting antena yang sesuai sangat penting karena akan mempengaruhi kinerja dari sebuah BTS dan jarak cakupan layanan sinyal yang dihasilkan.

Untuk menghitung besarnya sudut tilt antena dapat mengacu pada (13) [8].

p-ISSN:1693 - 2951; e-ISSN: 2503-2372 
$\alpha=\tan ^{-1} \frac{(H b-H r)}{\text { jarak } \times 1000}$

Dimana $\alpha$ merupakan nila besar sudut yang akan dihitung, $\mathrm{Hb}$ merupakan tinggi antena pemancar, $\mathrm{Hr}$ merupakan tinggi mobile station.

Proses tilting antena dapat dilakukan dengan 2 teknik yaitu sebagai berikut:

1) Mechanical Tilting : proses mengubah keadaan antena dari sisi fisik yaitu arah azimuth dan sudut kemiringan antena dimana akan mempengaruhi coverage area BTS. Perubahan arah mechanical tilting memiliki 2 arah yaitu uptilt (mengubah kemiringan antena lebih ke atas) dan downtilt (mengubah kemiringan antena lebih ke bawah). Proses uptilt dan downtilt dalam proses mechanical tilting dapat ditunjukan dalam Gambar 3.

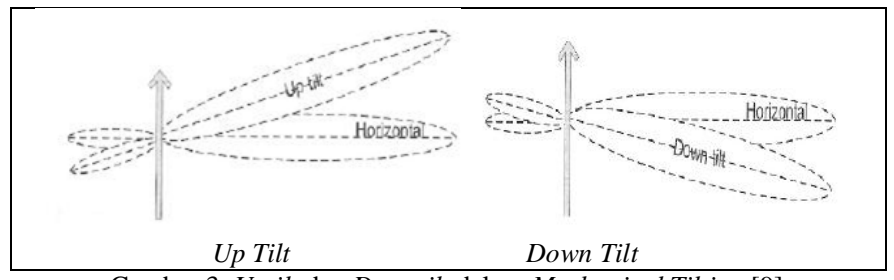

Gambar 3. Uptilt dan Downtilt dalam Mechanical Tilting [9]

2) Electrical Tilting : proses mengubah keadaan kelistrikan (phasa) antena, sehingga terjadi perubahan pada beamwidth antenna. Proses electrical tilting ini hanya akan bedampak pada ukuran main lobe yang dipancarkan oleh antena.

\section{G. Software Radio Planning Atoll}

Atoll merupakan software radio planning yang memungkinkan user/planner untuk membuat sebuah proyek perencanaan microwave ataupun perencanaan jaringan radio dengan satu set alat dan fitur yang komperhensif dan bahkan melihat prediksi coverage area sebuah site dalam satu aplikasi. Beberapa prediksi study dari cakupan area layanan dapat dikonfigurasikan sesuai kehendak user/planner [7]. Study yang disuguhkan diantaranya.

1) Coverage by signal level : Menghitung area yang tertutupi oleh level sinyal dari tiap cell.

2) Coverage by $\mathrm{C} /(\mathrm{I}+\mathrm{N})$ level (DL) : Menghitung area yang tertutupi oleh SINR downlink. SINR adalah perbandingan antara kuat sinyal dengan kuat interferensi ditambah noise yang dipancarkan oleh cell.

3) Coverage by $\mathrm{C} /(\mathrm{I}+\mathrm{N})$ level (UL) : Menghitung area yang tertutupi oleh SINR uplink.

4) Coverage by throughput (DL) : Menghitung area yang tertutupi oleh throughput downlink.

5) Coverage by throughput (UL) : Menghitung area yang tertutupi oleh throughput uplink.

\section{METODE PENELITIAN}

Metode yang digunakan dalam penelitian ini adalah dengan perhitungan dan simulasi menggunakan software Atoll. Flowchart metode penelitian dapat dilihat pada Gambar 4

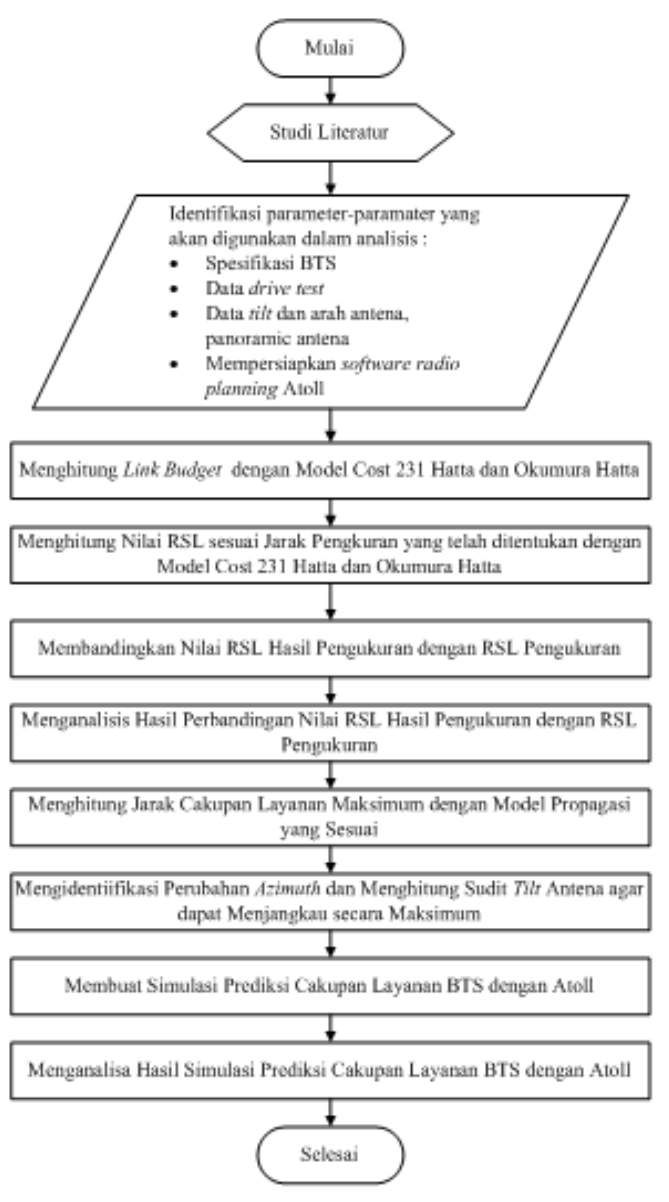

Gambar 4. Flowchart Metode Penelitian

Dalam penelitian ini, perhitungan cakupan layanan menggunakan model propagasi Cost-231 Hatta dan Okumura Hatta persamaan daerah urban. Perhitungan level penerimaan sinyal dilakukan sesuai jarak pengukuran yang telah ditentukan, kemudian hasil perhitungan dibandingkan dengan hasil pengukuran untuk mendapatkan margin level RSL. Margin RSL ini digunakan sebagai faktor koreksi untuk menghitung kembali jarak cakupan BTS yang mendekati kondisi sebenarnya di lapangan. Untuk model propagasi yang dipakai pada perhitungan jarak cakupan layanan maksimum akan dipilih dari hasil perhitungan RSL yang paling mendekati hasil pengukuran.

Setelah mengetahui jarak cakupan layanan maksimum dari BTS tersebut, maka akan dilakukan perhitungan besaran tilt antena yang sesuai dan identifikasi perubahan arah sektorisasi antena BTS sehingga cakupan layanan BTS ProtPeliatan sektor $\gamma$ dan BTS AnyarKaja sektor $\beta$ dapat menjangkau secara maksimal. Untuk membuktikan hasil kajian penataan sel tersebut, maka perlu adanya simulasi cakupan layanan menggunakan peta wilayah berkontur sehingga hasil kajian tersebut lebih optimal karena dengan adanya simulasi dapat membuktikan hasil kajian yang dilakukan. 


\section{HASIL DAN PEMBAHASAN}

\section{A. Perhitungan Link Budget}

Dalam menghitung jarak cakupan layanan BTS perlu dilakukan perhitungan link budget coverage area untuk mengetahui nilai product pathloss (Lp) dan total pathloss (Lpt). Parameter pengukuran yang digunakan dalam menghitung link budget dapat dilihat pada Tabel 3

TABEL III

PARAMETER PERHITUNGAN LINK BUDGET

\begin{tabular}{|l|c|c|c|c|}
\hline \multicolumn{1}{|c|}{ Parameter } & Simbol & Unit & Uplink & Downlink \\
\hline Frekuensi & $\mathrm{f}$ & $\mathrm{MHz}$ & 1925 & 2110 \\
\hline MS TX Power & $\mathrm{Pm}$ & $\mathrm{dBm}$ & 30 & -102 \\
\hline MS RX Sensitivity & $\mathrm{Sm}$ & $\mathrm{dBm}$ & & 2 \\
\hline MS Antenna Gain & $\mathrm{Gm}$ & $\mathrm{dBi}$ & 2 & 0 \\
\hline $\begin{array}{l}\text { MS Feeder Loss/Boddy } \\
\text { Loss }\end{array}$ & $\mathrm{Lm}$ & $\mathrm{dB}$ & 0 & 46 \\
\hline BS TX Power & $\mathrm{Pb}$ & $\mathrm{dBm}$ & & \\
\hline BS RX Sensitivity & $\mathrm{Sb}$ & $\mathrm{dBm}$ & -104 & \\
\hline BS Antenna Gain & $\mathrm{Gb}$ & $\mathrm{dBi}$ & 19,5 & 19,5 \\
\hline BS Diversity Gain & $\mathrm{Gd}$ & $\mathrm{dB}$ & 2,4 & \\
\hline BS Duplexer Loss & $\mathrm{Ld}$ & $\mathrm{dB}$ & 0,7 & 0,7 \\
\hline BS Jumper/Connector Loss & $\mathrm{Lj}$ & $\mathrm{dB}$ & 0,8 & 0,8 \\
\hline BS TX Filter Loss & $\mathrm{Ltf}$ & $\mathrm{dB}$ & 2 & 2 \\
\hline Feeder Loss per $\mathrm{m}$ & $\mathrm{Lf} / \mathrm{f}$ & $\mathrm{dB} / \mathrm{m}$ & \multicolumn{2}{|c|}{0,0636} \\
\hline Fade Margin & $\mathrm{Mf}$ & $\mathrm{dB}$ & \multicolumn{2}{c|}{5,5} \\
\hline Boddy Attenuation & $\mathrm{Ab}$ & $\mathrm{dB}$ & \multicolumn{2}{|c|}{2} \\
\hline Vehide Attenuation & $\mathrm{Av}$ & $\mathrm{dB}$ & \multicolumn{2}{c|}{0} \\
\hline Building Attenuation & $\mathrm{Avd}$ & $\mathrm{dB}$ & \multicolumn{2}{c|}{10} \\
\hline
\end{tabular}

Berdasarkan data pada Tabel 3, maka hasil perhitungan nilai product pathloss (Lp) dan total pathloss (Lpt) dapat dilihat pada Tabel 4 berikut.

TABEL IV

HASIL PERHITUNGAN LINK BUDGET

\begin{tabular}{|l|c|c|}
\hline & Uplink & Downlink \\
\hline Product Pathloss $(\mathrm{Lp})$ & $156,4 \mathrm{~dB}$ & $166 \mathrm{~dB}$ \\
\hline $\begin{array}{l}\text { Total feeder loss (Lf/f) } \\
\text { dengan tinggi antenna 21 m }\end{array}$ & $1,335 \mathrm{~dB}$ & $1,335 \mathrm{~dB}$ \\
\hline Total Pathloss $(\mathrm{Lpt})$ & $137,565 \mathrm{~dB}$ & $147,165 \mathrm{~dB}$ \\
\hline
\end{tabular}

Setelah mengetahui nilai total pathloss (Lpt), untuk mencari nilai jarak cakupan layanan BTS pada kondisi eksisting masukkan nilai tersebut kedalam (8) untuk model propagasi Okumura Hatta dan (10) untuk propagasi Cost 231 Hatta. Dengan nilai faktor koreksi antena mobile $\mathrm{a}(\mathrm{hm})$ sebesar $0,045 \mathrm{~dB}$, hasil perhitungan jarak cakupan yang didapat ditunjukkan pada Tabel 5 .

TABEL V

HASIL PERHITUNGAN JARAK CAKUPAN LAYANAN BTS PADA KONDISI EKSISTING

\begin{tabular}{|c|c|c|}
\hline \multirow{2}{*}{ Model Propagasi } & \multicolumn{2}{|c|}{$\begin{array}{c}\text { Jangkauan BTS ProtPeliatan Sektor } \gamma \text { dan } \\
\text { BTS AnyarKaja Sektor } \beta\end{array}$} \\
\cline { 2 - 3 } & Arah Uplink & Arah Downlink \\
\hline Cost 231 Hatta & $0,89 \mathrm{~km}$ & $1,48 \mathrm{~km}$ \\
\hline Okumura Hatta & $1,026 \mathrm{~km}$ & $1,73 \mathrm{~km}$ \\
\hline
\end{tabular}

Ketut Alit Sukertha Winaya: Analisis Penataan Sel Untuk ...
B. Perhitungan Nilai RSL

Sebelum menghitung nilai RSL, terlebih dahulu harus mengetahui nilai EIRP. Dengan menggunakan (11), nilai EIRP dapat dihitung sebagai berikut :

$$
\begin{aligned}
\mathrm{EIRP} & =\mathrm{P}_{\mathrm{TX}}+\mathrm{G}_{\mathrm{TX}}-\mathrm{L}_{\mathrm{TX}} \\
& =46+19,5-(1,335+0,8+0,7)=62,66 \mathrm{dBm} .
\end{aligned}
$$

Dalam perhitungan nilai RSL diambil beberapa sample titik pengukuran yakni jarak $0,5 \mathrm{~km}$ dan $0.7 \mathrm{~km}$ untuk BTS ProtPeliatan Sektor $\gamma$, serta jarak $0.45 \mathrm{~km}$ dan $0.7 \mathrm{~km}$ untuk BTS AnyarKaja Sektor $\beta$. Kemudian perlu dihitung terlebih dahulu nilai pathloss pada titik pengukuran tersebut untuk kedua BTS dengan model propagasi Cost 231 Hatta dan Okumura Hatta.

Hasil perhitungan nilai pathloss dan nilai RSL menggunakan model propagasi Cost 231 Hatta ditunjukkan pada Tabel 6 berikut

TABEL VI

HASIL PERHITUNGAN NILAI PATHLOSS DAN NILAI RSL

\begin{tabular}{|c|c|c|c|c|}
\hline \multirow{2}{*}{ BTS } & \multirow{2}{*}{$\begin{array}{l}\text { JarakPengukuran } \\
(\mathrm{km})\end{array}$} & \multirow{2}{*}{$\begin{array}{l}\text { Nilai Path } \\
\text { Loss (dBm) }\end{array}$} & \multicolumn{2}{|c|}{ Nilai RSL $(\mathrm{dBm})$} \\
\hline & & & Ukur & Hitung \\
\hline ProtPeliatan & 0,5 & 128,379 & -84 & $-89,21$ \\
\hline Sektor $\gamma$ & 0,7 & 133,675 & -86 & $-94,51$ \\
\hline AnyarKaja & 0,45 & 126,721 & -94 & $-87,56$ \\
\hline Sektor $\beta$ & 0,7 & 133,675 & -99 & $-94,51$ \\
\hline
\end{tabular}
MENGGUNAKAN MODEL PROPAGASI COST 231 HATTA

Hasil perhitungan nilai pathloss dan nilai RSL menggunakan model propagasi Okumura Hatta ditunjukkan pada Tabel 7 berikut

$$
\text { TABEL VII }
$$

HASIL PERHITUNGAN NILAI PATHLOSS DAN NILAI RSL MENGGUNAKAN MODEL PROPAGASI OKUMURA HATTA

\begin{tabular}{|l|c|c|c|c|}
\hline \multirow{2}{*}{ BTS } & \multirow{2}{*}{$\begin{array}{l}\text { JarakPengukuran } \\
(\mathrm{km})\end{array}$} & \multirow{2}{*}{\begin{tabular}{l} 
Nilai Path \\
\cline { 3 - 5 }
\end{tabular}} & Loss $(\mathrm{dBm})$ & \multicolumn{2}{|c|}{ Nilai RSL $(\mathrm{dBm})$} \\
\hline ProtPeliatan & 0,5 & 126,246 & -84 & Hitung \\
\cline { 2 - 5 } Sektor $\gamma$ & 0,7 & 131,542 & -86 & $-92,08$ \\
\hline AnyarKaja & 0,45 & 124,589 & -94 & $-85,42$ \\
\cline { 2 - 5 } Sektor $\beta$ & 0,7 & 131,542 & -99 & $-92,38$ \\
\hline
\end{tabular}

Dalam upaya untuk mendekatkan hasil perhitungan dan pengukuran, diperlukan suatu faktor koreksi (margin) yang didapatkan dari selisih antara RSL pengukuran dan RSL perhitungan. Faktor koreksi ini akan dimasukan kedalam perhitungan selanjutnya untuk menghitung kembali jarak cakupan layanan BTS. Dikarenakan jarak cakupan layanan terjauh pada kondisi eksisting berbeda dengan jarak cakupan layanan terjauh saat pengukuran, maka faktor koreksi yang digunakan adalah margin dari titik pengukuran terjauh $(0,7$ $\mathrm{km})$ Oleh karena itu dilakukan perbandingan RSL hasil pengukuran dan RSL perhitungan pada masing-masing BTS dengan model propagasi yang berbeda.

Perbandingan data hasil pengukuran dan hasil perhitungan nilai RSL pada BTS ProtPeliatan Sektor $\gamma$ menggunakan model propagasi yang berbeda ditunjukkan pada Tabel 8 berikut.

p-ISSN:1693 - 2951; e-ISSN: 2503-2372 
TABEL VIII

PERBANDINGAN RSL HASIL PENGUKURAN DENGAN RSL HASIL PERHITUNGAN PADA BTS PROTPELIATAN SEKTOR $\gamma$ MENGGUNAKAN MODEL PROPAGASI YANG BERBEDA

\begin{tabular}{|c|c|c|c|c|c|}
\hline \multirow[b]{2}{*}{ BTS } & \multirow{2}{*}{$\begin{array}{c}\text { Model } \\
\text { Propagasi }\end{array}$} & \multirow{2}{*}{$\begin{array}{c}\text { Jarak } \\
\text { Pengukuran } \\
(\mathrm{km})\end{array}$} & \multicolumn{2}{|c|}{ Nilai RSL (dBm) } & \multirow{2}{*}{$\begin{array}{c}\text { Margin } \\
(\mathrm{dBm})\end{array}$} \\
\hline & & & Ukur & Hitung & \\
\hline \multirow{4}{*}{$\begin{array}{c}\text { Prot } \\
\text { Peliatan } \\
\text { Sektor } \\
\gamma\end{array}$} & \multirow{2}{*}{$\begin{array}{ll}\text { Cost } 231 \\
\text { Hatta }\end{array}$} & 0,5 & -84 & $-87,08$ & $-5,21$ \\
\hline & & 0,7 & -86 & $-92,38$ & $-8,51$ \\
\hline & \multirow{2}{*}{$\begin{array}{l}\text { Okumura } \\
\text { Hatta }\end{array}$} & 0,45 & -94 & $-85,42$ & $-3,08$ \\
\hline & & 0,7 & -99 & $-92,38$ & $-6,38$ \\
\hline
\end{tabular}

Berdasarkan data pada Tabel 8, grafik perbandingannya ditunjukkan pada Gambar 5.

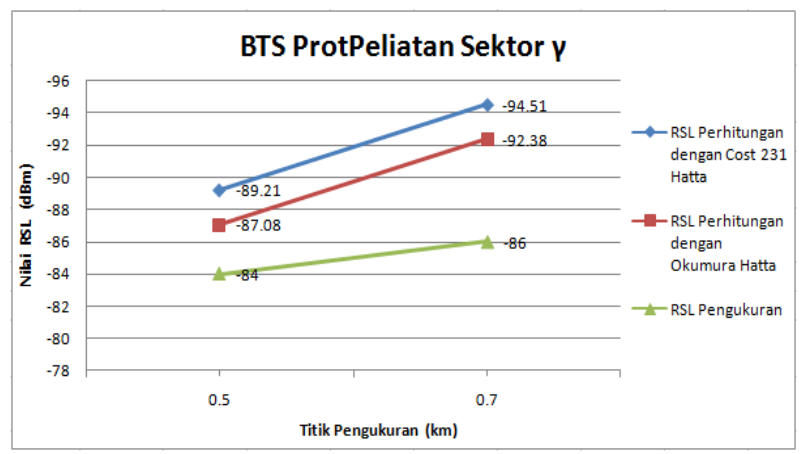

Gambar 5. Grafik Perbandingan RSL Pengukuran dan RSLPerhitungan dengan Model Propagasi yang Berbeda pada BTS Protpeliatan Sektor $\gamma$

Perbandingan data hasil pengukuran dan hasil perhitungan nilai RSL pada BTS AnyarKaja Sektor $\beta$ menggunakan model propagasi yang berbeda ditunjukkan pada Tabel 9 berikut

TABEL IX

PERBANDINGAN RSL HASIL PENGUKURAN DENGAN RSL HASIL PERHITUNGAN PADA BTS ANYARKAJA SEKTOR $\beta$ MENGGUNAKAN MODEL PROPAGASI YANG BERBEDA

\begin{tabular}{|c|c|c|c|c|c|}
\hline \multirow[t]{2}{*}{ BTS } & \multirow{2}{*}{$\begin{array}{c}\text { Model } \\
\text { Propagasi }\end{array}$} & \multirow{2}{*}{$\begin{array}{c}\text { Jarak } \\
\text { Pengukuran } \\
(\mathrm{km})\end{array}$} & \multicolumn{2}{|c|}{$\begin{array}{l}\text { Nilai RSL } \\
(\mathrm{dBm})\end{array}$} & \multirow{2}{*}{$\begin{array}{l}\text { Margin } \\
(\mathrm{dBm})\end{array}$} \\
\hline & & & Ukur & Hitung & \\
\hline \multirow{4}{*}{$\begin{array}{c}\text { AnyarKaja } \\
\text { Sektor } \beta\end{array}$} & \multirow{2}{*}{$\begin{array}{l}\text { Cost } 231 \\
\text { Hatta }\end{array}$} & 0,45 & -94 & $-87,56$ & $+6,44$ \\
\hline & & 0,7 & -99 & $-94,51$ & $+4,49$ \\
\hline & \multirow{2}{*}{$\begin{array}{l}\text { Okumura } \\
\text { Hatta }\end{array}$} & 0,45 & -94 & $-85,42$ & $+8,58$ \\
\hline & & 0,7 & -99 & $-92,38$ & $+6,62$ \\
\hline
\end{tabular}

Berdasarkan data pada Tabel 9, grafik perbandingan ditunjukkan pada Gambar 6.

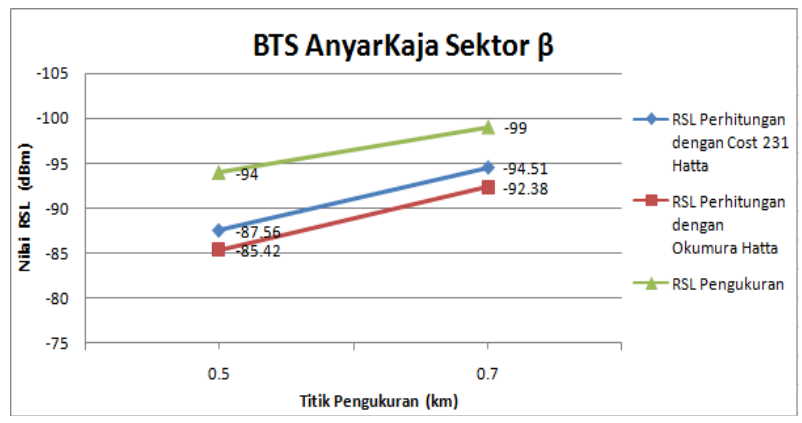

Gambar 6. Grafik Perbandingan RSL Pengukuran dan RSLPerhitungan dengan Model Propagasi yang Berbeda pada BTS AnyarKaja Sektor $\beta$
Berdasarkan Gambar 5 dan Gambar 6 dapat diketahui bahwa semakin jauh jarak pengukuran, maka nilai RSL yang diterima akan semakin besar begitupula sebaliknya. Pada BTS ProtPeliatan sektor $\gamma$, hasil perhitungan RSL yang paling mendekati hasil pengukuran yaitu dengan model Okumura Hatta dan pada BTS AnyarKaja hasil perhitungan RSL yang paling mendekati hasil pengukuran yaitu dengan model Cost 231 Hatta. Hasil perhitungan pada Tabel 5 diketahui bahwa jarak cakupan layanan terjauh BTS pada kondisi eksisting untuk model Cost 231 Hatta sejauh 1,48 km dan untuk model Okumura Hatta adalah sejauh $1,73 \mathrm{~km}$. Hal ini berbeda dengan jarak cakupan layanan terjauh yang didapat saat drive test dimana jarak cakupan layanan terjauh BTS adalah $0,7 \mathrm{~km}$. Oleh sebab itu faktor koreksi yang digunakan adalah margin dari titik pengukuran terjauh $(0,7 \mathrm{~km})$.

Untuk memperoleh perhitungan prediksi jarak cakupan layanan yang tepat dalam perhitungan jarak cakupan layanan maksimum, maka perhitungan pada BTS ProtPeliatan Sektor $\gamma$ akan menggunakan model propagasi Okumura Hatta dengan margin faktor koreksi sebesar $6,38 \mathrm{dBm}$, sedangkan perhitungan pada BTS AnyarKaja Sektor $\beta$ akan menggunakan model propagasi Cost 231 Hatta dengan margin faktor koreksi sebesar 4,49 dBm.

\section{Perhitungan Prediksi Cakupan Layanan BTS}

Untuk mendapatkan hasil perhitungan yang mendekati dengan kondisi eksisting, maka nilai Path Loss arah downlink $\left(\mathrm{Lpt}_{\text {downlink }}\right)$ akan dikurangi dengan margin pada jarak 0,7 km.

Nilai Lpt downlink adalah sebesar 147,165 dBm, nilai margin untuk BTS ProtPeliatan Sektor $\gamma$ adalah 6,38 dBm, dan margin untuk BTS AnyarKaja Sektor $\beta$ sebesar 4,49 dBm, sehingga,

\section{Lpt BTS ProtPeliatan Sektor $\gamma=147,165-6,38$$$
=140,785 \mathrm{dBm}
$$

dengan nilai Lpt 140,785 dBm, maka jarak cakupan layanan maksimum yang dihitung dengan (8) untuk BTS ProtPeliatan Sektor $\gamma$ adalah sejauh $1,17 \mathrm{~km}$.

$$
\text { Lpt BTS AnyarKaja Sektor } \begin{array}{r}
\beta=147,165-4,49 \\
=142,675 \mathrm{dBm}
\end{array}
$$

dengan nilai Lpt 142,675 dBm, maka jarak cakupan layanan maksimum yang dihitung dengan (10) untuk BTS AnyarKaja Sektor $\beta$ adalah sejauh $1,11 \mathrm{~km}$.

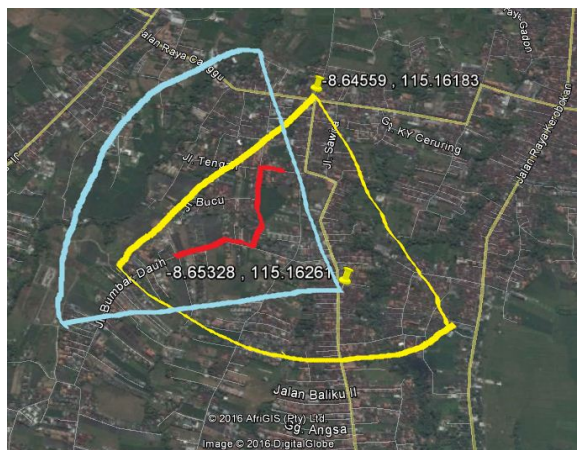

Gambar 7. Cakupan Layanan Maksimum BTS Protpeliatan Sektor $\gamma$ dan BTS AnyarKaja Sektor $\beta$ 
Gambar 7 menunjukkan cakupan layanan maksimum dari BTS Protpeliatan Sektor $\gamma$ dan BTS AnyarKaja Sektor $\beta$. Area dalam cakupan warna biru muda merupakan prediksi cakupan layanan maksimum dari BTS Protpeliatan Sektor $\gamma$ dan area dalam cakupan warna kuning merupakan prediksi cakupan layanan maksimum dari BTS AnyarKaja Sektor $\beta$. Garis warna merah dalam Gambar 7 menunjukan area Jl. Tengah I Kerobokan yang menjadi lokasi penelitian.

\section{Penataan Cakupan Sel}

Penataan cakupan layanan sel ini dilakukan dengan 2 cara yakni sektorisasi antenna (mengubah arah azimuth dari antenna) dan tilting antena.

1. Sektorisasi Antena

Arah azimuth dari BTS ProtPeliatan Sektor $\gamma$ adalah $300^{\circ}$ dan foto panoramic azimuth arah $300^{\circ}$ ditunjukkan dalam Gambar 8 berikut ini.

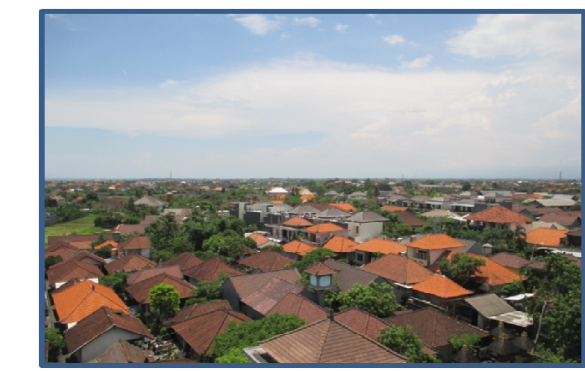

Gambar 8. Panoramic Azimuth $300^{\circ}$ BTS ProtPeliatan Sektor $\gamma$

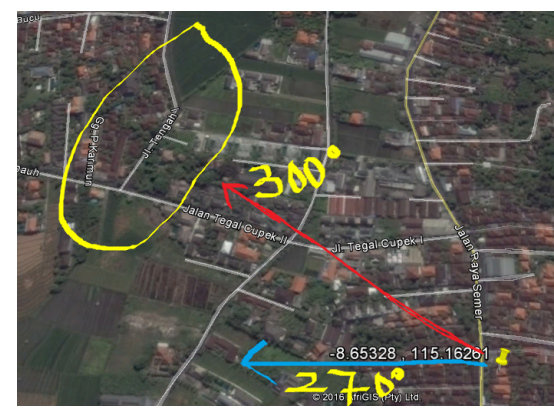

Gambar 9. Arah Azimuth $300^{\circ}$ BTS ProtPeliatan Sektor $\gamma$ dilihat Menggunakan Google Earth

Sedangkan arah azimuth dari BTS AnyarKaja Sektor $\beta$ adalah sebesar $180^{\circ}$. Foto panoramic dan Google Eart View Azimuth $180^{\circ}$ ditunjukkan dalam Gambar 10 dan Gambar 11 berikut.

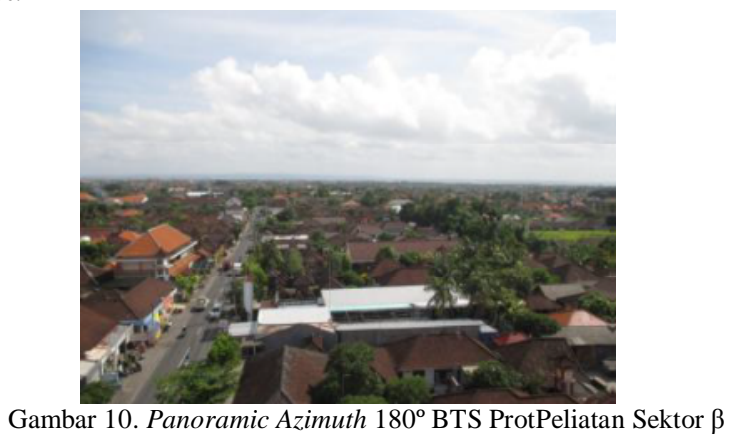

Ketut Alit Sukertha Winaya: Analisis Penataan Sel Untuk ...

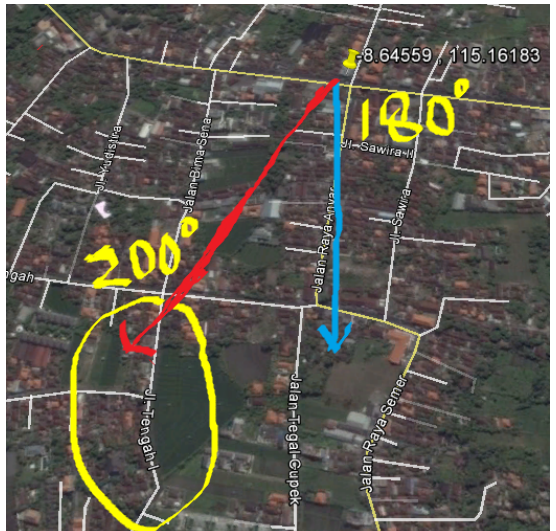

Gambar 11. Arah Azimuth $180^{\circ}$ dan $200^{\circ}$ pada BTS ProtPeliatan Sektor $\gamma$ dilihat Menggunakan Google Earth

Berdasarkan foto panoramic BTS pada Gambar 8 dan tampilan view dari Google Earth yang ditunjukkan pada Gambar 9 membuktikan bahwa arah sektorisasi antena BTS ProtPeliatan Sektor $\gamma$ sebesar $300^{\circ}$ sudah tepat mengarah ke Jl. Tengah I yang ditandai dengan lingkaran berwarna kuning dalam Gambar 9 dan menjangkau pemukiman penduduk disekitarnya sehingga tidak perlukan perubahan arah sektorisasi antena. Untuk arah sektorisasi antena BTS AnyarKaja Sektor $\beta$ sebesar $180^{\circ}$ yang ditunjukan pada Gambar 10 dan dibuktikan dengan tampilan view pada Google Earth dalam Gambar 11 menunjukkan arah antenna BTS AnyarKaja Sektor $\beta$ lebih mengarah ke Jl. Raya Anyar dan Jl. Tegal Cuplek. Sehingga untuk memberikan layanan yang maksimal di area Jl. Tengah I maka diperlukan perubahan arah antena sektor sebesar $20^{\circ}$ pada BTS AnyarKaja Sektor $\beta$ dari $180^{\circ}$ menjadi $200^{\circ}$.

\section{Tilting Antena}

Berdasarkan hasil perhitungan, diketahui bahwa jarak cakupan layanan maksimum BTS ProtPeliatan Sektor $\gamma$ adalah $1,17 \mathrm{~km}$. Untuk dapat menjangkau jarak tersebut, besar nilai sudut tilt antena BTS ProtPeliatan Sektor $\gamma$ dapat dihitung sebagai berikut.

$$
\begin{aligned}
\alpha & =\tan ^{-1} \frac{(\mathrm{Hb}-\mathrm{Hr})}{\text { jarak } \times 1000} \\
& =\tan ^{-1} \frac{(21-1,5)}{1,17 \times 1000} \\
& =\tan ^{-1} 0,0166 \\
& =0,95^{\circ}
\end{aligned}
$$

Sedangkan untuk dapat menjangkau jarak maksimum sejauh $1,11 \mathrm{~km}$, besar nilai sudut tilt antenna BTS AnyarKaja Sektor $\beta$ dapat dihitung sebagai berikut

$$
\begin{aligned}
\alpha & =\tan ^{-1} \frac{(\mathrm{Hb}-\mathrm{Hr})}{\operatorname{jarak} \times 1000} \\
& =\tan ^{-1} \frac{(21-1,5)}{1,11 \times 1000} \\
& =\tan ^{-1} 0,0175 \\
& =1^{\circ}
\end{aligned}
$$

p-ISSN:1693 - 2951; e-ISSN: 2503-2372 
Diketahui bahwa besar sudut mechanical tilt yang dipakai pada BTS ProtPeliatan sektor $\gamma$ dan BTS AnyarKaja sektor $\beta$ dalam kondisi ekesisting adalah sebesar $0^{\circ}$. Oleh karena itu, agar BTS ProtPeliatan sektor $\gamma$ dan BTS AnyarKaja sektor $\beta$ dapat melayani area Jl. Tengah I secara maksimum maka perlu dilakukan perubahan sudut tilt dengan mekanisme downtilt antena pada kedua BTS tersebut. Dengan perubahan tilt antena dari $0^{\circ}$ menjadi $0,95^{\circ}$ pada BTS ProtPeliatan sektor $\gamma$ dan perubahan dari $0^{\circ}$ menjadi $1^{\circ}$ pada BTS AnyarKaja sektor $\beta$ diharapkan area Jl. Tengah I dapat terlayani secara maksimal.

\section{E. Simulasi Prediksi Cakupan Layanan BTS}

Simulasi untuk melihat predikci cakupan layanan BTS ProtPeliatan sektor $\gamma$ dan BTS AnyarKaja sektor $\beta$ ini menggunakan software radio planning Atoll dimana prediksi cakupan layanan yang dihasilkan ditampilkan berdasarkan hasil prediksi by signal level. Adapaun parameter-parameter yang dipakai dalam simulasi dapat dilihat dalam Tabel 10.

TABEL X

PARAMETER YANG DIGUNAKAN DALAM SIMULASI PREDIKSI CAKUPAN LAYANAN SINYAL

\begin{tabular}{|c|c|c|}
\hline Paramter & $\begin{array}{c}\text { BTS Protpeliatan } \\
\text { Sektor } \gamma\end{array}$ & $\begin{array}{c}\text { BTS AnyarKaja } \\
\text { sektor } \beta\end{array}$ \\
\hline Tinggi Antena & $21 \mathrm{~m}$ & $21 \mathrm{~m}$ \\
\hline Gain & $19,5 \mathrm{~dB}$ & $19,5 \mathrm{~dB}$ \\
\hline Beamwidth & $120^{\circ}$ & $120^{\circ}$ \\
\hline Frekuensi & $2100 \mathrm{MHz}$ & $2100 \mathrm{MHz}$ \\
\hline Azimuth & $300^{\circ}$ & $200^{\circ}$ \\
\hline Mechanical Tilt & $0,95^{\circ}$ & $1^{\circ}$ \\
\hline Electrical Tilt & 4 & $66 \mathrm{dBm}$ \\
\hline Max Power & $46 \mathrm{dBm}$ & Cost 231 Hatta \\
\hline Model Propagasi & Okumura Hatta & \\
\hline
\end{tabular}

Simulasi prediksi cakupan layanan ini menggunakan peta wilayah berkontur sehingga cakupan layanan sinyal juga akan dipengaruhi oleh ketinggian wilayah. Tampilan peta wilayah berkontur dapat ditunjukan dalam Gambar 12

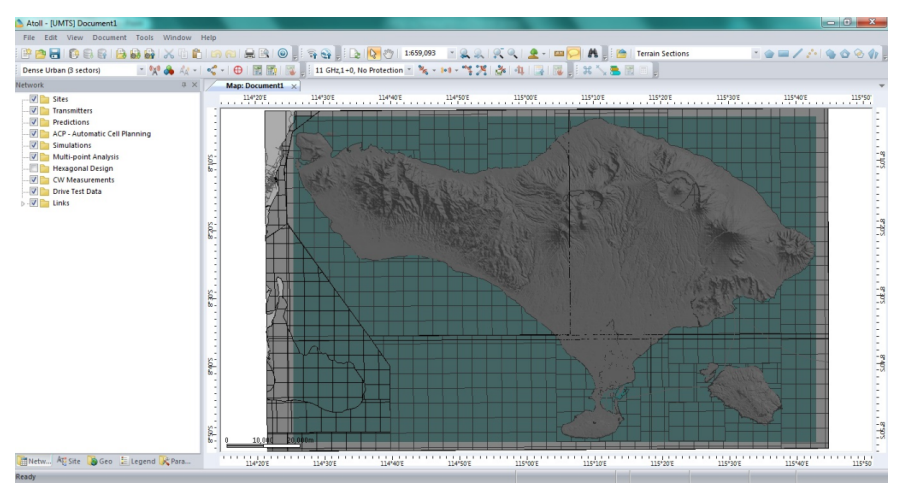

Gambar 12. Peta Wilayah Bali dengan Kontur Ketinggian

Berdasarkan data paramater yang digunakan dalam simulasi sesuai Tabel 5 diatas, hasil simulasi prediksi cakupan layanan sinyal yang dihasilkan dapat ditunjukkan pada Gambar 13 berikut.

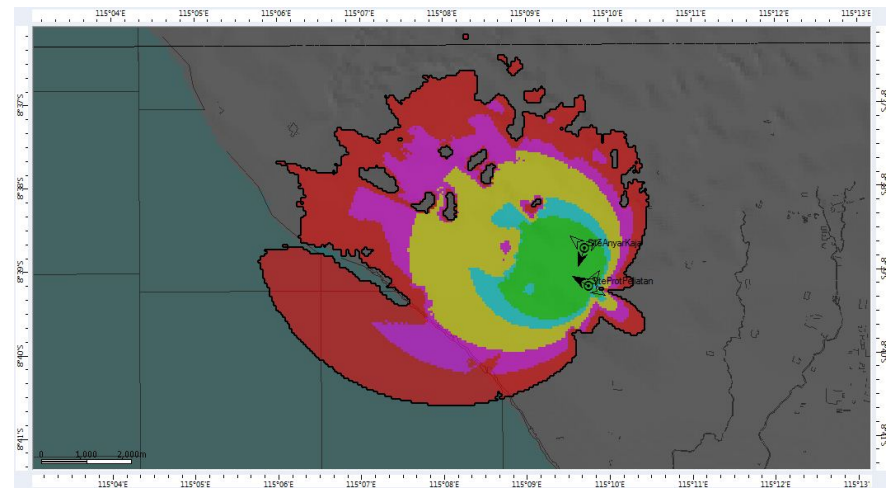

Gambar 13. Hasil Simulasi Prediksi Cakupan Layanan BTS ProtPeliatan sektor $\gamma$ dan BTS AnyarKaja sektor $\beta$ dalam Atoll

Berdasarkan Gambar 13 dapat dilihat orediksi cakupan layanan sinyal yang dihasilkan. Tiap warna yag dihasilkan menyatakan level kuat siyal yng diterima berbeda-beda. Hasil simulasi yang telah di export ke dalam Google Earth dapat ditunjukkan dalam Gambar 14 dibawah ini

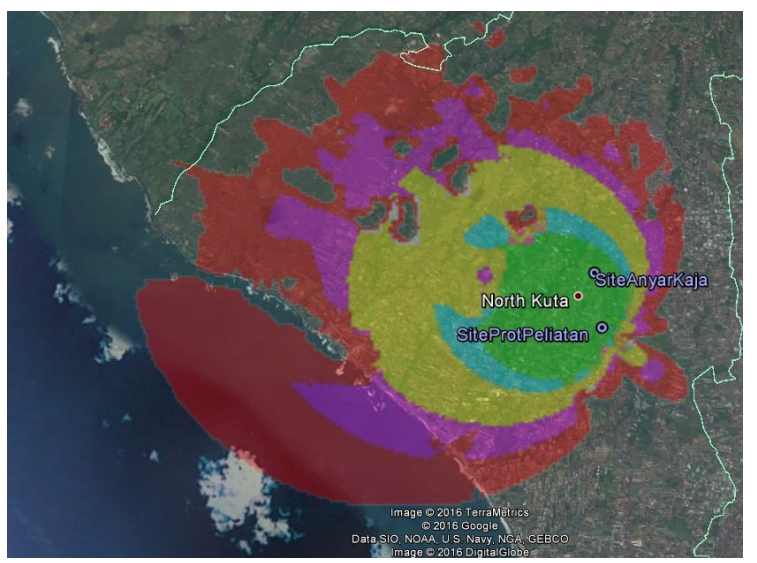

Gambar 14. Hasil Simulasi Prediksi Cakupan Layanan BTS ProtPeliatan sektor $\gamma$ dan BTS AnyarKaja sektor $\beta$ dalam dalam Google Earth

Dari Gambar 14 diatas diketahui bahwa area Jl. Tengah I Kerobokan telah mendapatkan layanan yang maksimal dari BTS ProtPeliatan sektor $\gamma$ dan BTS AnyarKaja sektor $\beta$ yang ditandai dalam cakupan layanan sinyal berwarna hijau. Berdasarkan data pada Gambar 2 dan Gambar, warna hijau menandakan level sinyal yang diterima di area tersebut berkisar antara $-74 \mathrm{dBm}$ sampai $-77 \mathrm{dBm}$. Level sinyal yang diterima tersebut dikategorikan dalam kondisi baik dan sudah memenuhi standar KPI (Key Performance Indicator).

\section{KESIMPULAN}

Berdasarkan hasil dan pembahasan yang telah dilakukan, maka dapat disimpulkan beberapa hal sebagai berikut :

1) Hasil perhitungan RSL yang paling mendekati hasil pengukuran untuk BTS ProtPeliatan sektor $\gamma$ adalah model Okumura Hatta dan untuk BTS AnyarKaja sektor $\beta$ adalah model Cost 231 Hatta. Sehingga dalam perhitungan jarak cakupan layanan maksimum pada BTS ProtPeliatan sektor $\gamma$ akan menggunakan model Okumura Hatta dan pada BTS AnyarKaja sektor $\beta$ akan menggunakan model Cost 231 Hatta 
2) Dalam menganalisis jarak cakupan layanan maksimum diperlukan sebuah faktor koreksi untuk mendekatkan hasil perhitungan dan hasil pengukuran yang didapatkan dari selisih antara RSL perhitungan dan RSL pengukuran. Faktor koreksi yang digunakan yakni pada titik pengukuran terjauh yaitu 0,7 $\mathrm{km}$ dengan nilai 6,38 $\mathrm{dBm}$ untuk BTS ProtPeliatan sektor $\gamma$ dan 4,49 dBm untuk BTS AnyarKaja sektor $\beta$

3) Sudut tilt antena BTS ProtPeliatan sektor $\gamma$ yang harus digunakan agar dapat menjangkau sejauh $1,17 \mathrm{~km}$ adalah sebesar $0,95^{\circ}$ dan sudut tilt antena BTS AnyarKaja sektor $\beta$ yang harus digunakan agar dapat menjangkau sejauh $1,11 \mathrm{~km}$ adalah sebesar $1^{\circ}$.

4) Agar cakupan layanan BTS ProtPeliatan sektor $\gamma$ dan BTS AnyarKaja sektor $\beta$ dapat menjangkau ke area Jl. Tengah I secara maksimal, maka perlu dilakukan mekanisme downtilt antena pada BTS ProtPeliatan sektor $\gamma$ yaitu dari $0^{\circ}$ menjadi $0,95^{\circ}$ dan pada BTS AnyarKaja sektor $\beta$ yaitu dari $0^{\circ}$ menjadi $1^{\circ}$. Selain itu, perlu dilakukan perubahan arah sektorisasi antena BTS AnyarKaja sektor $\beta$ sebesar $20^{\circ}$ yaitu dari $180^{\circ}$ menjadi $200^{\circ}$.

5) Berdasarkan hasil kajian yang dibuktikan dengan simulasi prediksi cakupan layanan sinyal menggunakan software radio planing Atoll, diketahui bahwa area Jl, Tengah I Kerobokan telah terlayani secara maksimal dengan level kuat sinyal yang dapat diterima berkisar antara $-74 \mathrm{dBm}$ sampai $-77 \mathrm{dBm}$ dan sudah memenuhi standard KPI.

\section{REFERENSI}

[1] R. Akbar. (2011). Konsep Dasar Sistem WCDMA. [Oline]. Available : http://repository.usu.ac.id/bitstream/123456789/25651/4/Chapter\%20II.p df.

[2] Sukrama, I Made., "Perencaaan Coverage Sistem GSM dan UMTS Telkomsel Wilayah Kuta Selatan".ST. Skripsi. Denpasar: Universitas Udayana, 2012.

[3] Sudiarta, P.K. (2015). Diktat Pengajaran Sistem Komunikasi Nirkabel. Denpasar : Universitas Udayana.

[4] A. Hikhmaturokhman dan L. Wardhana, $4 G$ Handbook, Edisi Bahasa Indonesia, Jakarta Selatan: www.nulisbuku.com, 2014.

[5] Pinem, Kevin Kristian., "Analisis Link Budget pada Pembangunan BTS Rooftop Cemara IV Sistem Telekomunikasi Seluler Berbasis GSM Studi Kasus PT. Telkomsel" ST. Skripsi. Medan : Universitas Sumatera Utara, 2014.

[6] Irawan, Ardi Dwi., "Analisis Kualitas Daya Pancar Antena Tongyu TDQ182020DE-65F pada Pembangunan BTS Flexi Multiradio (FMR) Nokia Siemens Network (NSN)," ST. Skripsi, Pontianak: Universitas Tanjung Pura, 2013.

[7] Putra, T.G.A.S., Sudiarta, P.K, dan Diafari, I.G.A.K., "Analisis Pengaruh Model Propagasi dan Perubahan Tilt Antena Terhadap Coverage Area Sistem Long Term Evolution Menggunakan Software Atoll”. E-Journal SPEKTRUM Vol.2 No.4, 2015.

[8] Wirawan, Kadek Hady Surya., "Analisis Optimasi Coverage Area BTS Jimbaran dan BTS GWK Untuk Layanan Telkom Flexi”. ST. Skripsi. Denpasar : Universitas Udayana, 2012.

[9] Syahdan, Permana,. (2014). Audit Site, Electrical and Mechanical Tilting. [Online]. Avalilable: http://permanasyahdan.blogspot.com/2014/07/auditsite-electrical-and mechanical.html 